\title{
Urszula Zarosa, Status moralny zwierząt, PWN, Warszawa 2017, ss. 276
}

DOI: http://dx.doi.org/10.12775/RF.2017.009

Książka Urszuli Zarosy Status moralny zwierząt podejmuje problem naszych relacji ze zwierzętami. Autorka włącza się w niezwykle aktualną debatę dotyczącą zmian w sposobie traktowania istot innych gatunków, która ma wymiar nie tylko teoretyczny, ale też i praktyczny. Dotyczy bowiem zmian w prawie, czy sposobie odżywania się. Omawiana praca odwołuje się do trzech obszarów badań i rozważań: etyki, nauk przyrodniczych (fizjologia, etologia itp.) oraz praktyki. Dzięki temu może zainteresować zarówno filozofów, czy osoby zajmujące się animal studies, jak i czytelników chcących dowiedzieć się, o co chodzi na przykład w sporach dotyczących polowań czy sposobu hodowli kur.

Autorka zaczyna od wyjaśnienia, czym jest status moralny, na jakiej podstawie jest on nadawany i dlaczego jest ważny. Wyjaśnia, w jaki sposób nadanie statusu moralnego wpływa na nasze odnoszenie się do zwierząt. Ze szczególną uwagą rozważa tutaj trzy kryteria: życie (za Albertem Schweitzerem), bycie osobą (Immanuel Kant, Tom Regan, personalizm) oraz odczuwanie. Przy czym to pierwsze odrzuca jako nakładające na nas obowiązki niemożliwe do zrealizowania. Drugie zaś uznaje za nazbyt problematyczne, aby mogło się stać jedynym czy najważniejszym kryterium przyznawania statusu moralnego. Opowiada się za sformułowanym po raz pierwszy przez Jeremiego Benthama podglądem, że to zdolność do odczuwania cierpienia jest podstawą do przypisywania interesów i prawa istotom żywym.

Takie wprowadzenie pozwala śledzić dalszą argumentację także tym, którzy nie zajmują się filozofią czy etyką. Chociaż Zarosa przywołuje koncepcje J. Locke’a czy I. Kanta, to jednak czyni to w sposób na tyle przystępny, że nawet czytelnicy po raz pierwszy spotykający się z tymi nazwiskami powinni być w stanie zrozumieć treść rozdziału i zdobyć pewne podstawy niezbędne dla właściwego zrozumienia dalszych części książki. W podobny sposób napisany jest też rozdział trzeci zatytułowany Umyst zwierząt omawiający kwestie odczuwania bólu, emocji czy świadomości i samoświadomości u przedstawicieli innych gatun- 
ków. Zagadnienia te prezentowane są na ciekawych przykładach, ale też z licznymi odwołaniami do najnowszych badań naukowych. Autorka omawia argumenty na rzecz zdolności odczuwania przez zwierzęta bólu, doznawania emocji i posiadania świadomości. Tę ostatnią odróżnia od samoświadomości wymagającej możliwości przyjmowania perspektywy innej osoby (innego osobnika) czy mentalnej podróży w czasie. Przywołuje najnowsze eksperymenty, potwierdzając istnienie tych zdolności u człowiekowatych, ale też u świń, delfinów czy fok. Sporo uwagi poświęca także komunikacji wśród zwierząt oraz posługiwaniu się przez nie językiem, w tym prostymi pojęciami (kategoriami).

Bardziej teoretyczny charakter mają rozdziały drugi i czwarty traktujące o utylitaryzmie preferencji oraz o znaczeniu potencjalności $\mathrm{w}$ nadawaniu statusu moralnego. Rozdział drugi Zwierzęta z punktu widzenia utylitaryzmu preferencji to zwięzła prezentacja koncepcji Petera Singera i jego zasady równego rozważenia interesów. Oprócz zasady równego rozważenia interesów omawia on także projekt expanding circle, czyli rozszerzającego się kręgu altruizmu oraz przybliża czytelnikom pojęcie szowinizmu gatunkowego. Chociaż Zarosa nie kryje swojej sympatii do tego stanowiska, to nie pomija opinii krytycznych. Wskazuje na brak precyzyjnej definicji interesu oraz na trudności z mierzeniem siły preferencji. Wspomina również o problemach ze stosowaniem zasady równego rozważenia interesów, która wymaga odrzucenia wszelkiej stronniczości. Przywołuje także stanowiska sprzeciwiające się w ogóle przyznawaniu zwierzętom statusu moralnego oparte na przypisywaniu ludziom specyficznych własności przyznających nam wyższy status moralny, czy też szczególne relacje łączące nas z przedstawicielami własnego gatunku. Pozwala to czytelnikowi wyrobić sobie zdanie, niekoniecznie zgodne z poglądami Singera czy Zarosy. Niestety autorka pomija krytykę utylitaryzmu preferencji przeprowadzoną przez Regana, który stara się udowodnić, że zasada równego rozważenia interesów nie zapewnia zwierzętom dostatecznej ochrony przez pozbawianiem życia i różnymi formami eksploatacji.

Natomiast rozdział czwarty, choć dotyczy przede wszystkim zwierząt (tego, czy należy brać pod uwagę jedynie ich uświadomione, czy też także nieświadome i potencjalne interesy), to dotyka również kwestii płodów i ludzi znajdujących się w śpiączce. Odnosi się zatem do innych aktualnych debat dotyczących eutanazji, przerywania ciąży czy zapłodnienia in vitro. Autorka stara się odpowiedzieć na pytanie, czy i dlaczego potencjalność jest moralnie istotna oraz kiedy się ona zaczyna. Mimo złożonego i mocno teoretycznego charakteru tych zagadnień omawia je w sposób dość zrozumiały, posługując się często eksperymentami myślowymi.

Moim zdaniem najciekawszy jest jednak ostatni rozdział Status moralny zwierzą a konsekwencje praktyczne traktujący o konkretnych impli- 
kacjach wcześniej zaprezentowanych zagadnień. Dobitnie pokazuje on, że nie mamy tu do czynienia z czysto akademicką dyskusją o stopniowaniu statusu moralnego czy rodzajach potencjalności, ale ze sprawami, z którymi każdy z nas styka się codziennie. Zwierzęta dostarczają nam pożywienia, ale też i rozrywki, testujemy na nich nowe leki i kosmety$\mathrm{ki}$, trzymamy je w domach w charakterze pupili. Powszechne wykorzystanie zwierząt dla potrzeb człowieka sprawia, że proceder ten staje się tak oczywisty, że niemal niezauważalny. Tymczasem autorka pisze nie tylko o zwierzętach hodowanych na pokarm (w większości metodami chowu przemysłowego) czy wykorzystywanych do testów laboratoryjnych. Dostrzega również takie formy eksploatacji zwierząt, jak pokazy cyrkowe, ogrody zoologiczne, delfinaria czy wreszcie przetrzymywanie w charakterze domowych pupili. Nie pomija również problemu zwierząt dzikich i zapewnienia im dobrostanu. W tym kontekście wspomina o polowaniach i roli myśliwych w kontrolowaniu populacji zwierząt. Jest to kwestia gorąco dyskutowana obecnie w Polsce i angażująca aktywistów prozwierzęcych. O ich działaniach zresztą Zarosa też pisze: zarysowuje historię aktywizmu prozwierzęcego, daje przykłady najbardziej znanych akcji, omawia podejście pragmatyczne i abolicjonistyczne oraz stosowane $w$ ich ramach metody.

Książka Zarosy skłania do refleksji nad tym, co kryje się za naszymi powszechnymi, z pozoru tak niewinnymi praktykami, jak wizyta w zoo czy zakup kosmetyków. Pokazuje też, że filozoficzne rozważania wcale nie muszą być czymś całkowicie oderwanym od rzeczywistości. Przeciwnie, mogą prowadzić do rezultatów znajdujących zastosowanie w codziennym życiu, takich jak wspomniana zasada równego rozważenia interesów. Zarosa prezentuje jej przydatność w konkretnych przypadkach, z jakimi każdy z nas może się spotkać - podczas zakupów żywności czy kosmetyków czy przy wyborze form spędzania wolnego czasu.

„Status moralny zwierząt" to dość udane połączenie pracy naukowej i popularyzatorskiej. Autorka pisze w sposób przystępny, zrozumiałym językiem, ale nie spłyca omawianych zagadnień. Jeśli ktoś tylko słyszał o takich kwestiach, jak status moralny, szowinizm gatunkowy czy w ogóle problem relacji ze zwierzętami, to ma szansę dowiedzieć się, o co w nich chodzi. Lektura książki może zachęcić go do sięgnięcia po inne pozycje dokładniej omawiające te problemy. Przystępność polega bowiem też na skrótowej, choć niejednostronnej, prezentacji poruszanej problematyki. Można uznać to za pewien kompromis - dłuższe rozważania mogłyby zniechęcić czytelników mniej zorientowanych w subtelnościach filozoficznych debat. Oczywiście osoby szukające pogłębionej analizy poruszanych w książce zagadnień mogą się czuć rozczarowane faktem, że autorka raczej zarysowuje problemy, niż je dokładnie analizuje.

Mankamentem pracy jest też jej nieco mylący tytuł. Dotyczy ona bowiem nie tyle kwestii statusu moralnego zwierząt $\mathrm{w}$ ogóle, ile w ramach 
utylitaryzmu preferencji, zwłaszcza w wersji Singera. Autorka deklaruje to już na pierwszej stronie wstępu. Informacja taka znajduje się również na ostatniej stronie okładki. Choć jest ona wprowadzająca w błąd - nie jest to bowiem ani dokładne, ani pierwsze w Polsce opracowanie etyki Singera. Była ona już omawiana (pod pewnymi względami nawet dokładniej) w pracach Grzegorza Francuza, Doroty Probuckiej oraz Tomasza Pietrzykowskiego, choć nie jako jedyna czy wiodąca. Poza tym w książce Zarosy o utylitaryzmie preferencji w wersji Singerowskiej traktuje bezpośrednio tylko jeden, liczący około 30 stron, rozdział. Zasadzie równego poszanowania interesów jeden z podrozdziałów książeczki Spór o prawa zwierząt poświęcił Pietrzykowski. Jest ona zestawiona ze stanowiskiem Regana jako jedna z podstaw ideologii ruchu wyzwolenia zwierząt. W podobny sposób - w opozycji do teorii praw zwierząt omawia koncepcję Singera Probucka, której Filozoficzne podstawy prawa zwierząt poświęcone są prezentacji stanowiska konkurencyjnego wobec Singerowskiego. Dlatego też koncentruje się ona na krytyce zasad utylitaryzmu preferencji dokonanej przez Regana. Natomiast Francuz w pracy Strategie przypisywania statusu moralnego istotom żywym wymienia Singera jako jednego z przedstawicieli egalitarystycznej strategii nadawania statusu moralnego. W tym zestawieniu Status moralny zwierzat jest faktycznie jedyną pozycją koncentrującą się na utylitaryzmie preferencji, a nie prezentującą to stanowisko jako jedno z wielu czy opozycyjne wobec omawianego. O oryginalności książki Zarosy stanowi jednak, moim zdaniem, przede wszystkim próba konsekwentnego zastosowania Singerowskiej zasady równego rozważenia interesów do rozwiązywania praktycznych dylematów, jakie pojawiają się w naszych kontaktach ze zwierzętami.

Książkę Status moralny zwierząt warto przeczytać bez względu na to, czy jest się osobą zorientowaną $\mathrm{w}$ przedstawianej $\mathrm{w}$ niej problematyce, czy chce się dopiero czegoś na ten temat dowiedzieć. Prezentuje ona jedno z najważniejszych stanowisk $\mathrm{w}$ debacie dotyczącej relacji człowiek-zwierzę. Poza tym, co szczególnie ważne, dostarcza wiedzy, którą można wykorzystać, śledząc debatę publiczną dotyczącą chociażby polowań czy wegetarianizmu, ale także, jak wcześniej wspominałam, eutanazji czy aborcji. Pozwala też z innej perspektywy spojrzeć na nasze zwyczaje żywieniowe czy preferencje zakupowe i dostrzec, że mogą one podlegać ocenie moralnej oraz stać się narzędziem walki o poprawę losu zwierząt.

Barbara Grabowska

Uniwersytet Mikołaja Kopernika, Toruń e-mail: barbaragrabowska@wp.pl 